PROBLEMS

OF MANAGEMENT

IN THE $21^{\text {st }}$ CENTURY

Vol. 9, No. 2, 2014

MANAGEMENT OF SELF-DEFENSE OF THE MUNICIPALITIES - PREPARATION FOR THE DECISION-MAKING PROCESS AT DISASTERS

\author{
Marianna Dobó \\ Eszterházy Károly College, Eger, Hungary \\ E-mail: mariann.dobo@ektf.hu
}

\begin{abstract}
The research, which was started in 2013 focuses on the decision-making process after vis-mayor situations (Dobó, 2013). Disaster Management in Hungary is a less known and researched area. However, over the last years natural problems had great impact on the decision making process of the local government (Csefkó, 1997). The disasters transformed the processes that had been working so far. The examination of the changed decisions became very important. Researches were carried out by the Disaster Management Department of National University of Public Service. One of the most important projects is the Critical infrastructure protection that could provide practical knowledge about the topic. The decision-making process after the crisis had not been analysed in previous studies.

This research can be divided into several parts. First, there is exploration of the theoretical frameworks, laws and regulations. The decisions of the local government and the disaster management process can be presented by becoming familiar with the previous disasters. The most important stage will be the examination of the post-disaster period when the roles and the transformation of the players can be demonstrated.

The methodology is complex. In the first phase, after consideration of the literature, the focus is on the changes of the law. The second stage contains media monitoring, document and map examination as well as interviews with the actors. In the third stage, the observation comes as a new method to the second phase: cooperative decision making process, crisis communication replacement, social reconciliation. The topic at any time is up to date due to the fact that while the preparedness for a crisis has become more urgent, the prediction of vis-mayor situations and consequently, the preparation is almost impossible. In this context, the decision-making process of 15 municipalities, which are now live every day of their flood, pour of the river-wall or red mud disaster and after the storm, was examined.

The creation of a theoretical framework and their presentation on conferences happened so far. Processing the methodology and case studies of the disaster management are currently going on. The presentation of the achievement is expected in the autumn period.
\end{abstract}

Key words: crisis communication, decision-making, declared period's administrative function, legal framework.

\title{
Introduction
}

This study summarises the administrative tasks and mechanism of the averting of danger with regard of the legal framework for EU (Directive 82/501/EEC + 96/82/EEC Seveso Seveso II), UN (Conventions) (OECD Convention) and national legislation is defined by the Geneva Convention I-II. and the Additional Protocol. I will present the tasks of the municipalities during the emergencies. These tasks do not include only the direct intervention, but also include the prevention, protection and restoration tasks (French, 1992). 
The challenges of the normal period, the period before the introduction and the classified, declared period's administrative functions were analysed separately.

The settlement's fund plan, the preparation, the players of the defence and the integration of the crisis communication into the defence management process are presented.

Social crises are considered preventable, however natural disasters are unpredictable. The approach of crises on the social level is indicated by many signs, however, these signals are often not interpreted accurately by those with whom they will have a big influence in the future. In times of disaster, people's lives, health or property may suffer significant injury or damage. In addition, the elimination of the results and effects of the crisis may simply be beyond the crisis management capabilities of the responsible organisations. The ability to communicate effectively with the affected population can break down and so decision making then needs different participants and will follow different rules. It requires strict, continuous and smooth cooperation between local government and central organizations, or requires the help of international aid.

\section{Problem of Research}

Difficult situations always force actions and decisions. Only some of these situations happen as a result of a crisis that has built up over time, most of them manifest in the decision making process when reacting to a situation which is sudden and unforeseen (Dobó, 2014, p. 125). Former priorities are usually set aside and temporarily or permanently changed. In many cases, there is a paradigm shift, as the goalposts are moved (Röpke, 1942,). Literary sources remind us that force majeure in itself does not necessarily result in a crisis; it can be avoided or prevented. Based on this information, there is a need for those small indicators, events, differences in mindset, the ways in which the participants make decisions, which if present, will prevent force majeure from becoming the catalyst that leads to, compounds and escalates a crisis (Jacobson, 1979).

\section{Research Focus}

The questions which provide the basis for the topics of the research started in 2013 :

a) The first is the impact of past trauma on the present; e.g. is experience gained from the previous situations used in the current decision-making? Is force majeure really the result of unexpected situations, or is it recurring? Are there anomalies in the decision-making process? What are the major conflicts; can a significant difference be observed in the roles, participants, and the design process?

b) It is believed that the second most important point is re-positioning. I analyse how well the participants adapt to the new situation, their impact on the decision-making processes, as well as the relationship with and the management of recent emergencies. What are the priorities of the decision-making processes? Did the decision-making process speed up? How do things happen usually during and after the crisis? Is there a shift in attitude in the decisionmaking process?

Ultimately, they all relate to one question: What is the new status quo? - Has the situation been restored to that which came before the event or are there also continuing effects present? Has there been a total change in attitude and policy?

c) The third major part of the research is the area of social negotiation, as local society is sensitive to whether the crisis has caused a crisis of legitimacy. This can best be researched using the election topics of the following campaign period, as well as the results of the elections. 
PROBLEMS

OF MANAGEMENT

IN THE $21^{\text {st }}$ CENTURY Vol. 9, No. 2, 2014

134

\section{Methodology of Research}

In the first phase of the multi-year research the decisions taken during disasters such as floods, embankment collapses and the red toxic sludge spill were examined. During the research project, surveys will be carried out on several occasions. Firstly, the main aim is to become familiarised with the relevant representative bodies, the decision making process and problems of the organisations and try to understand how the organisations develop their standards, their members` roles and their places within the organisations. Secondly, the relationship and the interaction process between the organisations and their members were examined.

\section{General Background of Research}

Defence is an activity that involves the prevention of disasters, the aversion of direct threats, the elimination of the causes, the reduction of the harmful effects, the protection of the inhabitants' property and well being, the provision of basic conditions in disaster-stricken areas, rescue, the creation of the conditions for recovery. One of the most important conditions of this is that the legal background is in place and the tasks and framework necessary for compliance are determined. The most important in this process is to determine and implement the administrative tasks and ensure they are carried out in a verifiable way. The first step is the creation of national legislation taking into account international principles and legal framework and responsibilities.

a) International principles:

EU (82/501/EEC + 96/82/EEC Directive Seveso Seveso II), UN (Conventions) (OECD Convention) defines national legislation I and II of the Geneva Convention. Additional Protocol.

In 1976, there was an accident in Italy during which a significant amount of dioxins contaminated the environment. As a result of the accident, as a reminder, they created Seveso I and then Seveso II, which became legislation later on, not just for environmental protection. According to the legislation the Member States have to take appropriate and effective steps in order to prevent serious accidents. One of the most important parts of the legislation is the adherence to the obligation to notify, in the case of companies who hold large quantities of hazardous materials on site, this to the authorities. In addition the company needs to draw up a plan which contains a serious accident prevention plan. Special attention should be paid to the safety management system, infrastructure design, construction and maintenance, as well as the preparation of emergency action plans (82/501/EEC + 96/82/EEC Directive Seveso Seveso II).

Member States need to ensure that those companies who are under obligation to submit a safety report also prepare an internal emergency action plan, and send the information necessary to make a contingency plan, to the competent authorities. Affected companies need to ensure - at least every three years- that the emergency plans are reviewed, inspected, modified as necessary and are kept up to date and relevant. Should accidents occur, there is compulsory notification, as this can save the environment from further catastrophes. Of course, there is also a provision to close those businesses which constitute too great a threat to the environment or have incomplete reports and response plans.

b) National legislation:

In 2011, the government created a new law relating to disaster management. This has defined the tasks of the participants, clarifying their legal responsibilities, and the action sequence (protocol) in the event of an emergency. The main participants are: the Government, the Minister responsible for defence against disasters, the Head of the central governmental administrative body, the county, metropolitan and local safety committee, the chairman of the 
local defence committee, the mayor and other voluntary organizations in the town (2§. 2011. CXXVIII. ).

The Government and the Minister responsible for defence against disasters were given complex tasks by the law. It defines the mutual sharing of information and assistance as parts of the duties of state agencies. In addition, the Law states the following as key tasks: education, training, scientific research and technical development activities and the creation of a disaster management information system. It determines the resources and budget for these activities. (5 $\S .2011$. CXXVIII). This law was the first to define the national risk evaluation and assessment requirements. These are the tasks of the preparation period. However, the law sets a lot of tasks for the government in the event of an emergency as well. Defence management, the coordination of the implementation and post-disaster reconstruction are important tasks.

The operation of the official disaster management body is the responsibility of the Minister. The law requires reports to be prepared and handed in to Parliament every three years, which is not sufficient in view of current situations and events. The system of the responsibilities of the civil defence and its current status needs to be carried out in the same way. The head of the central administrative body is made responsible for planning, organization and control. The announcements, the authorities permission and the regulatory tasks required for their application make up a significant part (9 $\$$. 2011. CXXVIII). Combining the telecommunications, computing and the different sectors` measurement and control systems, can help make a more effective defence in the event of a disaster.

It is important to see how they can involve trade organisations and the voluntary civil organisations in a defence plan. The law favours those who have the ability to do more than just take part locally. The Law provides for their preparation and makes provisions for creating their operating conditions. The defence committees need to be set up on a county, metropolitan and local level. It is important in their activities, that in their own areas of jurisdiction they manage and coordinate preparation, direct the defence preparation activities of the Mayor and organize the mutual assistance between services and provide information to the population.

The most important role at a local level was given to the mayor. He is the one who organizes the preparation and the defence in his jurisdiction. Of course, he needs to work closely together with disaster relief organizations and the local defence committee.

During the preparation stage, he has to draw up the threat response plan, and has to direct the defence preparations. These require many skills. The continual training is coordinated by the county disaster management agency. The Mayor, the Notary and others who participate in local disaster management regularly take part in relevant training activities. An important part of the training is learning about the methods of sufficient communication and the appropriate use of crisis communication. During the defence the Mayor directs the local disaster management activities in the village or town, organizes and manages the protection, rescue, relocation and return of the population, with the professional guidance of the official disaster management body (Hornyacsek, Csépeiné, \& Veres, 2010 p. 47). He organizes and directs the protection of material goods and the provision of basic needs for the population. Cooperation between neighbouring settlements is very important here.

\section{Administrative Tasks during Non Emergencies, Before the Announcement of a State of Emergency and during a State of Emergency}

Local councils have responsibilities not only during the state of emergency, but also during the prevention, protection and recovery periods as well. Crisis preparation activities must be continuous even when there is no perceived threat.

Force majeure situations are not predictable, their common feature is that the events occur unexpectedly and when important decisions are taken there is a lack of information. In 
PROBLEMS

OF MANAGEMENT

IN THE $21^{\text {st }}$ CENTURY Vol. 9, No. 2, 2014

136

addition, the events drive the decisions, to the extent that if the decision making is delayed, worse and worse decisions are made. A unique situation can occur when there is a sense of temporary loss of control, paired with the feeling that the activities should be kept under constant control. The traditional decision making process breaks down, local, operational decisions are emphasized and the role of short-term planning increases. These require the participants to be organised.

For them to carry out their tasks and fulfil their roles properly there has to be a definition as to what constitutes a state of emergency, as well as what the roles and responsibilities of the decision makers during these periods are. During any state of emergency the continuous control of the all aspects of the defence plan require timely decision-making. The available resources and conditions for their efficient use have to be provided in a manner that ensures that they comply with the needs of exercising extraordinary power and the requirements of the law.

During "normality" the requirements regarding the activities of the state leadership, the Hungarian army and the law enforcement agencies are defined.

At this time, priority should be given to the completion of expected disaster risk studies, planning, and practicing activities, which can reduce the heightened stress situation during emergencies.

A competent person should check and evaluate the preparedness of local employers and local civil defence organizations. It is also important to maintain the information and warning equipment and designate the relevant buildings and infrastructure which can be used during an emergency.

In the period immediately preceding the introduction of states of emergency, changes have taken place (state security, foreign policy, natural disaster, industrial disaster, social unrest). The danger of an event occurring is present, but there is still a chance for prevention or resolution, so there is still time to act. Defence preparations must be made, taking into account the extent of the risk, but also keeping in mind the possibility of prevention as well. Additionally, attention must be paid to the transition with the description and implementation of regulations, prevention of risks and the theoretical and practical knowledge for avoiding disasters and their consequences (Hornyacsek, Csépeiné, \& Veres, 2010 p. 59).

In a state of emergency the search and rescue and first aid are urgent tasks. In this case the Mayor organizes and manages the preparation for and implementation of the administrative tasks relating to the involvement of military assistance and the Notary directs the work of the supporting officials.

During this period it is essential that he directs the defence tasks of the settlement, he can initiate the use of civil defence organizations. At this time provisions must be made for the rotation, rest and supply of the participating defence forces. Continuous contact is an important part of the tasks of this period and this should be carried out by mayors of the surrounding villages or the members of the local security committee. This task is not optional, cooperation and information dissemination is compulsory. Restoration tasks must not be forgotten about either. Restoration needs to be done in a specific order. The goal is to restore the conditions to the ones existing prior to the disaster, to process the lessons learnt and utilise them in the preparation for the next period (18 §. 2011. CXXVIII).

\section{Protection and Threat Prevention Master Plan}

An important aspect of the development of the plan is to be suitable for the nature of the expected threats. It should be realistic, explore the available human, financial, technical possibilities, and it is important to be consistent with the guidance of the local defence committees. Periodic re-evaluations of the plans are necessary to add new responsibilities. The basic defence plan and the threat prevention master plan of the settlement are prepared by the defence 
headquarters and the civil defence office. It is approved by the Mayor and should also have the approval of the district civil defence headquarters. The disaster management authority provides a plan template to help in its' preparation. The authority points out that in addition to being up to date it is also important for it to be independent so it can be used on its own without other documents. It has to be short, clear, to the point and of course feasible.

The City Civilian Defence Master Plan consists of two parts, one part is the evacuation and admission plan and the other is the warning and summoning plan. It is very important to have accurate and up to date street names on the town map. It was recommended that if the street names have changed recently, the old ones should be indicated on the map as well. Particular attention should be paid to the provision of power, telecommunications and a clean water supply. In addition to the maps other informative materials need to be prepared about the escape routes and conditions for mobilization. The registers of the settlement are useful but not essential during an effective defence, to know the headcount, the age groups, occupations and expertise of the population.

In disaster management the co-operation and precise planning are very important. The following figure illustrates this. The planning includes several areas: the operational intervention, the preparation of detailed instructions, as well as designing how the public and other organizations will work together. The long-term planning includes the experience of the cases done earlier and the knowledge of the current situation. To understand the current situation you need to know the composition and the number of the population, the condition and status of the infrastructure and settlement's location too. The available tools should be taken into inventory. The water supply and other security objects should be known as well as the study of the geographical environment. The possible emergencies and the location and resources of the operative intervention should not be disregarded during the designing process. During the planning, by having accurate and up to date information, should be defined that what can be an alarm, which are the levels and order of the intervention and how can the original situation be set back (Figure 1).

\section{Figure 1: Planning.}

\begin{tabular}{|c|c|c|}
\hline $\begin{array}{l}\text { planning of operative } \\
\text { intervention }\end{array}$ & $\begin{array}{l}\text { The study of the } \\
\text { management of similar } \\
\text { situations that have } \\
\text { occurred }\end{array}$ & $\begin{array}{l}\text { The study of the } \\
\text { Geographical } \\
\text { enviroment }\end{array}$ \\
\hline $\begin{array}{l}\text { develop detailed } \\
\text { instructions }\end{array}$ & $\begin{array}{l}\text { Collecting data: population, } \\
\text { infrastucture, economy, public } \\
\text { institutions, objects / building, } \\
\text { weather, available resources, } \\
\text { fuel, supply of victims }\end{array}$ & $\begin{array}{l}\text { limitation and } \\
\text { localization of the risk } \\
\text { situation }\end{array}$ \\
\hline $\begin{array}{l}\text { cooperation and } \\
\text { contact with other } \\
\text { organisations }\end{array}$ & \begin{tabular}{l}
\multicolumn{1}{c}{$\downarrow$} \\
develop measures, warning, \\
intervention, Restoring \\
original state
\end{tabular} & \\
\hline
\end{tabular}


PROBLEMS

OF MANAGEMENT

IN THE $21^{\text {st }}$ CENTURY Vol. 9, No. 2, 2014

138

\section{Planning in the preparation period}

Consultation with the population during the planning stage can have a key role. With the appropriate consultation process and with the involvement of the opinions of the social environment, conflicts can be prevented and any conflict of interest created can be resolved in less time and more safely in many cases, however advanced modelling greatly speeds up the development of the different solutions (French, 1992).

Communication plays a key role in disaster management. Improper use can result in panic or can trigger hysteria (Lazarus, 1966). Communication includes keeping the population, the people involved in relief efforts and also everyone else informed. Hence, it is important to maintain mutual cooperation with the media in general. The preparation of publications should become a habit listing the risk sources, hazard characteristics, prevention methods, defence regulations for the effects of disasters, alarm signals, evacuation rules and the addresses and phone numbers of participating rescue organizations (Röpke, 1942).

In case of emergency, there are many rules which govern communication, how they should look and what the communication should contain. It is important to accommodate the media and provide them with sufficient and relevant information, as this can help the defence process by satisfying the needs for information and may help prevent "disaster tourism".

The information should be extensive, but to the point and should not include uncertain and vague references either.

It is important to prepare: the Presidents of the local defence committee, the mayors, local government leaders, teachers, notaries, students and local population in how to communicate. In the preparation of the population, publications and forums can help (if the ratio of ethnicities is higher than 5\% then in their native languages too), in these, the use of expressions which could cause panic should be avoided.

\section{Conclusions}

Difficult situations always force actions and decisions. Only some of these situations happen as a result of a crisis that has built up over time. Most of them manifest in the decision making processes, when reacting to a situation which is due to unforeseen events. Former priorities are usually set aside and temporarily and/or permanently changed, in many cases, there is a paradigm shift, as the goalposts are moved. In case of the settlements taking part in the study, it is important that the local councils from the wider environment are not working in an optimal manner, just as the period just before the crisis did not change a perfect equilibrium. The cooperation between members of the local community is emphasised in times of crisis, but in the following period, hidden conflicts, anger and resentment may come to the surface.

\section{References}

Csefkó, F. (1997). A helyi önkormányzati rendszer. Location: Dialóg Campus.

Dobó, M. (2013). Önkormányzatok döntéshozatala a vis mayor helyzetek után. In. Á. Ferencz, (Ed.) Gazdálkodás és menedzsment. pp. 841-847. Kecskeméti Főiskola, Kecskemét.

Dobó, M. (2014). Önkormányzatok döntései a vis mayor helyzetek következtében - a válság és a krízis fogalmi eltérései. pp.124-129. J. Karlovitz János (Ed.): Kulturális és társadalmi sokszínüség a változó gazdasági környezetben. Komárno: International Research Institute, p. 125.

French, J. (1992). Reflections on public office. Texas Town and City.

Hornyacsek, J., Csépeiné, Sz. P., \& Veres, V. (2010). Önkormányzati vezetők felkészitése a védelmi feladatokra. Publisher: Zrínyi Miklós Nemzetvédelmi Egyetem.

Jacobson, G. F. (1979). Crisis-oriented therapy. Psychiatric of North America, 2, 39-54

Lazarus, R. S. (1966). Psychological stress and the coping process. New York: McGraw-Hill 
Röpke, W. (1942). The social crisis of our time. The University Chicago Press.

2011. évi CXXVIII. törvény a katasztrófavédelemröl és a hozzá kapcsolódó egyes törvények módosításáPROBLEMS

ról. Retrieved from http://net.jogtar.hu/jr/gen/hjegy_doc.cgi?docid=A1100128.TV

EU (82/501/EEC + 96/82/EEC Directive Seveso Seveso II), UN (Conventions) (OECD Convention). Retrieved from http://europa.eu/legislation_summaries/environment/civil_protection/121215_en.htm

Advised by Iwona Gorzeń-Mitka, Czestochowa University of Technology, Poland

Received: May 09, 2014

Accepted: August 05, 2014

Marianna Dobó

PhD., Assistant Professor, Eszterházy Károly College, 4 Egészségház Street, Eger, Hungary.

E-mail: mariann.dobo@ektf.hu 